\title{
The Value of Terminal Ileum Intubation During Colonoscopy
}

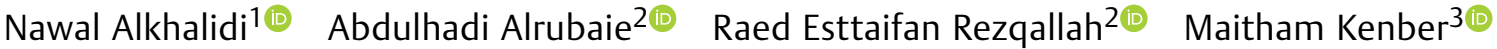 \\ ${ }^{1}$ Department of Gastroenterology and Hepatology Center Baghdad, \\ Baghdad, Iraq \\ 2 Department of Surgery, Alkindy College of Medicine/University of \\ Baghdad, University of Baghdad, Baghdad, Iraq \\ 3 Vice President for Scientific Affaires, University of Al-Ameed, Karbala. \\ Address for correspondence Dr. Abdulhadi L. Alrubaie, MD, \\ Department of Surgery, Alkindy College of Medicine/University of \\ Baghdad, University of Baghdad, Baghdad, Iraq \\ (e-mail: hadirubaie@yahoo.com).
}

Professor of Surgery, Departement of Surgery, University of Kufa, Iraq

J Coloproctol 2022;42(1):59-62.

\begin{abstract}
Keywords

- colonoscopy

- terminal ileum

- ileocecal intubation

- Crohn's disease

It is uncertain whether terminal ileum intubation should be performed routinely during colonoscopy, as there is uncertainty regarding its diagnostic value. The aim of the present study is to assess the diagnostic yield of terminal ileum intubation during colonoscopy according to indications for colonoscopy. This is a cross-sectional study in which the results of 294 total colonoscopy procedures were reviewed; ileal intubation was performed in 269 (91.49\%) patients. The indications for colonoscopy, the results of ileoscopy, and the histopathological results of ileal biopsies were evaluated.

A total of 54 (20\%) out of 269 patients who had successful intubation into the terminal ileum showed macroscopic abnormalities on the terminal ileum. Biopsies were positive in 4 out of 54 (7.4\%); all were of Crohn disease. Two were erosions (9.5\%.) and 2 were ulcers (18.8\%). The two erosions were presented as abdominal pain, abdominal pain and alternating bowel motion. Those with ulcers were presented with diarrhea and perianal disease.

Conclusions Considering the low diagnostic yield of ileal intubation during colonoscopy, the decision to perform ileoscopy or not during colonoscopy needs to be made on a case-by-case basis. However, routine ileal intubation, brief attempts should be considered despite low diagnostic yield.
\end{abstract}

\section{Introduction}

It is dubious whether terminal ileum intubation ought to be performed routinely during colonoscopy as there is uncertainty regarding its diagnostic value. ${ }^{1}$ Concerns regarding complete colonoscopy dictates that cecal landmarks such as the ileocecal valve and the appendiceal opening during colonoscopy are largely accepted, although some regard ileal intubation as the evidence of a complete procedure. ${ }^{2-4}$ Although ileoscopy is not practiced routinely, it may be beneficial in some patients with right lower quadrant pain, diarrhea of unknown cause, inflammatory bowel disease, hematochezia, and suspected ileocecal tuberculosis. ${ }^{5-10}$ Most studies on ileoscopy were done Western countries, and less in Asian countries. ${ }^{8,11}$ Ileocolonoscopy is the procedure of choice for chronic nonbloody diarrhea of unknown received

June 13, 2021

accepted after revision

August 6, 2021
DOI https://doi.org/

10.1055/s-0041-1739298.

ISSN 2237-9363. (c) 2022. Sociedade Brasileira de Coloproctologia. All rights reserved.

This is an open access article published by Thieme under the terms of the Creative Commons Attribution-NonDerivative-NonCommercial-License, permitting copying and reproduction so long as the original work is given appropriate credit. Contents may not be used for commercial purposes, or adapted, remixed, transformed or built upon. (https://creativecommons.org/ licenses/by-nc-nd/4.0/)

Thieme Revinter Publicações Ltda., Rua do Matoso 170, Rio de Janeiro, RJ, CEP 20270-135, Brazil 
origin. A histopathological examination of multiple sites is crucial to diagnose microscopic colitis. The routine ileal biopsy of normally appearing mucosa assessed by standard-resolution white-light ileoscopy is controversial because of the reported low diagnostic yield. ${ }^{12}$ Currently, the position employed to intubate the ileum is with the patient in the left lateral position and entering the valve at the 6 o'clock position. However, we have sometimes encountered difficulty when performing ileoscopy in this position, leading to extra time being consumed during busy endoscopy lists. During such difficult procedures, placing the patient in the prone position using A 'down and left' technique facilitated ileal intubation. ${ }^{13,14}$ As performing a biopsy of an endoscopically normal terminal ileum is controversial. ${ }^{15-18}$ The aim of the present study is to assess the diagnostic yield of terminal ileum intubation during colonoscopy according to indications for colonoscopy.

\section{Methods}

This is a cross-sectional study in which the results of 294 total colonoscopy procedures were reviewed; ileal intubations were performed in 269 patients

All procedures at Gastroenterology and Hepatology Center were performed at the gastroenterology and hepatology center in Baghdad from April 2018 to September 2020 using Olympus, Lucera CF-H260AL.

The degree of bowel preparation was reasonable in all patients. Midazolam and pethidine were used for conscious sedation with doses according to the needs of each individual patient.

The indications for colonoscopy, the results of ileoscopy, and the histopathological results of ileal biopsies were evaluated.

Biopsy was taken in all macroscopic abnormalities of the terminal ileum.

An abnormality was considered as being clinically significant if it raised a new diagnosis or if it led to specific investigations or management, such as inflammatory bowel disease, intestinal tuberculosis, Behcet's disease, and tumors; otherwise they were considered as nonspecific.

\section{Inclusion Criteria}

Indications for Colonoscopy:
1-Abdominal pain: abdominal pain only or with diarrhea, constipation, alternating bowel motion, persistent or recurrent abdominal pain, and hematochezia with or without fever.

2-Without abdominal pain: including constipation, alternating bowel motion, diarrhea, and bleeding from rectum only.

\section{Exclusion Criteria}

Asymptomatic medical check-up. Follow-up of known surgical or medical gastrointestinal conditions.

\section{Statistical Analysis}

Statistical analysis was performed with IBM SPSS Statistics for Windows, version 23.0 (IBM Corp., Armonk, NY, USA).

\section{Results}

A total of 54 (20\%) out of 269 patients who underwent successful terminal ileum intubation showed macroscopic abnormalities on the terminal ileum, which included ulcers, erosions, congestion, and nodular mucosa.

In 22 out of 269 patients (8\%), there was mucosal nodularity. In 21 (7.8\%) patients, there was congestion and/or erosions. In 11 (4\%) patients, the abnormalities were ulcers. A total of 65 (24.16\%) patients presented with haematochesia; $10(3 \%)$ of them associated with abdominal pain; 30 (11.1\%) without abdominal pain; and 25 (9.2\%) without abdominal pain but with abnormal bowel motion. - Tables 1,2,3

\section{Biopsy Results}

Biopsies of the 54 patients with macroscopical abnormalities of the terminal ileum were positive in 4 (7.4\%) patients, which corresponded to $1.4 \%$ of all ileal intubations. All were of Crohn's disease; 2 were erosions (9.5\%) out of 21 patients with congestion/erosions; and 2 were ulcers (18.1\%) out of 11 ulcer patients.

\section{Diagnostic Biopsies According to Clinical Indications for Colonoscopy (-Table 4)}

The two patients with erosions presented with abdominal pain or with abdominal pain and alternating bowel motion.

Table 1 indications and findings in abdominal pain with other symptoms

\begin{tabular}{|c|c|c|c|c|c|}
\hline Indications & $n$ (out of 269) (\%) & $\begin{array}{l}\text { Abnormal terminal } \\
\text { ileum } n(\%)\end{array}$ & Nodular & Congestion /erosion & Ulcer \\
\hline Abdominal pain & $26(9.6 \%)$ & $5(19.2)$ & 3 & 2 & 0 \\
\hline with diarrhea & $35(13 \%)$ & $10(28.5)$ & 3 & 4 & 3 \\
\hline with constipation & $38(14.1 \%)$ & $7(16.4)$ & 5 & 1 & 1 \\
\hline and alternating bowel motion & $30(11.1 \%)$ & $9(27.5)$ & 2 & 6 & 1 \\
\hline with bleeding from rectum & $10(3.7 \%)$ & $0(0 \%)$ & 0 & 0 & 0 \\
\hline Total & $139(51.6 \%)$ & $31(22.3)$ & 13 & 13 & 5 \\
\hline
\end{tabular}


Table 2 Indications and findings in patients without abdominal pain

\begin{tabular}{|l|l|l|l|l|l|}
\hline Indications & $\boldsymbol{n}$ (out of 269) (\%) & $\begin{array}{l}\text { Abnormal terminal } \\
\text { ileum } \boldsymbol{n}(\%)\end{array}$ & Nodular & $\begin{array}{l}\text { Congestion/ } \\
\text { erosion }\end{array}$ & Ulcer \\
\hline Constipation & $27(10 \%)$ & $4(14.8 \%)$ & 3 & 1 & 0 \\
\hline Bleeding from rectum & $30(11.1 \%)$ & $5(16.6 \%)$ & 3 & 0 & 2 \\
\hline $\begin{array}{l}\text { Bleeding from rectum with } \\
\text { abnormal bowel motion }\end{array}$ & $25(9.2 \%)$ & $4(16 \%)$ & 2 & 1 & 1 \\
\hline Diarrhea & $16(5.9 \%)$ & $4(25 \%)$ & 1 & 2 & 1 \\
\hline Total & $98(36.4 \%)$ & $17(17.34 \%)$ & 9 & 4 & 4 \\
\hline
\end{tabular}

Table 3 Miscellaneous indications

\begin{tabular}{|l|l|l|l|l|l|}
\hline Indications & $\boldsymbol{n}(\%)$ & $\begin{array}{l}\text { Abnormal terminal } \\
\text { ileum } \boldsymbol{n}(\%)\end{array}$ & Nodular & $\begin{array}{l}\text { Congestion/ } \\
\text { erosion }\end{array}$ & Ulcer \\
\hline Suspected irritable bowel syndrome & $11(4 \%)$ & $4(36.6 \%)$ & 0 & 3 & 1 \\
\hline Tumors & $8(2.9 \%)$ & $0(0 \%)$ & 0 & 0 & 0 \\
\hline Perianal complaints & $6(2.2 \%)$ & $2(33.3 \%)$ & 0 & 1 & 1 \\
\hline Anemia and melaena & $3(1.1 \%)$ & $0(0 \%)$ & 0 & 0 & 0 \\
\hline Liver secondaries & $4(1.4 \%)$ & $0(0 \%)$ & 0 & 0 & 0 \\
\hline Total & $32(11.8 \%)$ & $6(18.75 \%)$ & 0 & 4 & 2 \\
\hline
\end{tabular}

Table 4 Relation of clinical indications endoscopic findings and histopathological biopsy results

\begin{tabular}{|l|l|l|}
\hline Clinical indication & $\begin{array}{l}\text { Abnormal } \\
\text { ileoscopic } \\
\text { findings }\end{array}$ & $\begin{array}{l}\text { Histopathological } \\
\text { biopsy }\end{array}$ \\
\hline Abdominal pain & 1 erosion & Crohn's disease \\
\hline Diarrhea & 1 ulceration & Crohn's disease \\
\hline Perianal disease & 1 ulceration & Crohn's disease \\
\hline $\begin{array}{l}\text { Abdominal pain } \\
\text { with alternating } \\
\text { bowel motion }\end{array}$ & 1 erosion & Crohn's disease \\
\hline Total & $4 / 54(7.5 \%)$ & \\
\hline
\end{tabular}

Those with ulcers presented with diarrhea and perianal disease.

\section{Discussion}

In the present study, the most common indication for ileal intubation was abdominal pain (51.6\%) followed by haematochezia (24.16\%), constipation (10\%), diarrhea (5.9\%), and suspected irritable bowel syndrome (4\%). There were $91 \%$ successful ileal intubations. There were $20 \%$ abnormal macroscopical findings in the terminal ileum, which were mucosal nodularity (8\%), congestion and/or erosions (7.8\%), and ulcers (4\%). Positive biopsies were $7.4 \%$, all corresponding to Crohn's disease.

Compared with Akere et al., ${ }^{19}$ the indication for intubation was abdominal pain (26.2\%), haematochezia (25\%), constipation (14.2\%), and diarrhea (14.2\%); the rate of successful ileal intubation was $30.9 \%$; abnormal macroscopical findings were $2.4 \%$, including ulcers, polypoid lesions, and cobblestone appearance, which may be attributed to the wide disparity in successful intubations. The rate of positive biopsies was 93.7\%, including chronic nonspecific ileitis, acute chronic ileitis, and tuberculous ileitis, which can be attributed to differences in the diets of the patients.

Velidedeoğlu et al. ${ }^{20}$ showed the most common indications for intubation are diarrhea (39\%), haematochezia (28\%), abdominal pain (26\%), abdominal bloating (18\%), constipation (5\%), and mucoid rectal discharge (5\%). Macroscopical abnormalities were ulcers and/or erosions (39\%), mucosal nodularity $18 \%$, and erythema was $42 \%$.

A study by Wijewantha et al. ${ }^{21}$ showed a successful intubation rate of $90.15 \%$ and $47 / 81$ (58\%) positive biopsies. This high percent because ileal intubation done for only indicated intubation as this will be $(6.15 \%)$ from the overall. From those, 28/47 (59.5\%) were Crohn's disease, 6/47 (12.7\%) were tuberculosis, $8 / 47$ (17\%) were ileitis due to resolving infection, and 5/47 (10.6\%) were drug-induced ileitis. There were macroscopical abnormalities in 34/47 (72.3\%), of which $21 / 34(61.7 \%)$ were mild inflammation or erosions, and $13 / 34$ (38.3\%) were few aphthous ulcers. The most common indications of terminal ileoscopy were diarrhea in $29.31 \%$, abdominal pain in $15.83 \%$, suspected irritable bowel syndrome in $10.6 \%$, and anemia in $9.81 \%$.

\section{Conclusion}

High ileal intubation rates may be achieved without complications. 
The diagnostic yield of the procedure is very low; therefore, the decision to perform ileoscopy or not during colonoscopy needs to be made on a case-by-case basis.

However, routine ileal intubation, brief attempts should be considered despite low diagnostic yield, it may be useful to improve or maintain endoscopic skills, especially in a training setting.

\section{Ethical Approval and Permission}

Ethical permission was granted by the scientific committee in Gastroenterology and Hepatology Center.

\section{Financial Support and Scholarship}

None to declare

\section{Conflict of Interests}

The authors have no conflict of interests to declare.

\section{Acknowledgments}

We thank all the nursing and support members of the staff of the Endoscopy Unit and members of staff of the Department of Pathology, Hepatology and Gastrointestinal disease Center, Baghdad, Iraq, for their assistance toward the success of the present research work.

\section{References}

1 Jeong SH, Lee KJ, Kim YB, Kwon HC, Sin SJ, Chung JY. Diagnostic value of terminal ileum intubation during colonoscopy.J Gastroenterol Hepatol 2008;23(01):51-55. Doi: 10.1111/j.1440-1746.2007.05151.x

2 Börsch G, Schmidt G. Endoscopy of the terminal ileum. Diagnostic yield in 400 consecutive examinations. Dis Colon Rectum 1985;28 (07):499-501

3 Farrar WD, Sawhney MS, Nelson DB, Lederle FA, Bond JH. Colorectal cancers found after a complete colonoscopy. Clin Gastroenterol Hepatol 2006;4(10):1259-1264

4 Abadie SN, Haque M. Documentation of complete colonoscopy; can we do it better? Gastrointest Endosc 2008;67(05):AB247-AB248

5 Cherian S, Singh P. Is routine ileoscopy useful? An observational study of procedure times, diagnostic yield, and learning curve. Am J Gastroenterol 2004;99(12):2324-2329

6 Yoong KK, Heymann T. It is not worthwhile to perform ileoscopy on all patients. Surg Endosc 2006;20(05):809-811

7 Kennedy G, Larson D, Wolff B, Winter D, Petersen B, Larson M. Routine ileal intubation during screening colonoscopy: a useful maneuver? Surg Endosc 2008;22(12):2606-2608
8 Bhasin DK, Goenka MK, Dhavan S, Dass K, Singh K. Diagnostic value of ileoscopy: a report from India. J Clin Gastroenterol 2000; 31(02):144-146

9 Misra SP, Dwivedi M, Misra V. Ileoscopy in 39 hematochezia patients with normal colonoscopy. World J Gastroenterol 2006; 12(19):3101-3104

10 Zwas FR, Bonheim NA, Berken CA, Gray S. Diagnostic yield of routine ileoscopy. Am J Gastroenterol 1995;90(09):1441-1443

11 Niriella MA, De Silva AP, Dayaratne AH, et al. Prevalence of inflammatory bowel disease in two districts of Sri Lanka: a hospital based survey. BMC Gastroenterol 2010;10:32

12 Borsotti E, Barberio B, D'Incà R, et al. Terminal ileum ileoscopy and histology in patients undergoing high-definition colonoscopy with virtual chromoendoscopy for chronic nonbloody diarrhea: A prospective, multicenter study. United European Gastroenterol J 2019;7(07):974-981

13 De Silva AP, Kumarasena RS, Perera Keragala SD, et al. The prone 12 o'clock position reduces ileal intubation time during colonoscopy compared to the left lateral 6 o'clock (standard) position. BMC Gastroenterol 2011;11:89

14 Ansari A, Soon SY, Saunders BP, Sanderson JD. A prospective study of the technical feasibility of ileoscopy at colonoscopy. Scand J Gastroenterol 2003;38(11):1184-1186

15 Byrne MF, Power DG, Keeling AN, Kay E, Murray FE, Patchett SE. Combined terminal ileoscopy and biopsy is superior to small bowel follow-through in detecting terminal ileal pathology. Dig Liver Dis 2004;36(02):147-152

16 McHugh JB, Appelman HD, McKenna BJ. The diagnostic value of endoscopic terminal ileum biopsies. Am J Gastroenterol 2007;102 (05):1084-1089

17 Melton SD, Feagins LA, Saboorian MH, Genta RM. Ileal biopsy: Clinical indications, endoscopic and histopathologic findings in 10,000 patients. Dig Liver Dis 2011;43(03):199-203

18 Powell N, Hayee BH, Yeoh DP, Rowbotham DS, Saxena V, McNair A. Terminal ileal photography or biopsy to verify total colonoscopy: does the endoscope agree with the microscope? Gastrointest Endosc 2007;66(02):320-325

19 Akere A, Otegbayo JA, Tejan EA. Terminal ileum intubation during colonoscopy: Should it be routinely performed on all patients? Trop J Med Res 2017;20(01):66-69

20 Velidedeoğlu M, Enes Arıkan A, Kağan Zengin A. Diagnostic value of terminal ileum biopsies in patients with abnormal terminal ileum mucosal appearance. Ulus Cerrahi Derg 2015;31(03): $152-156$

21 Wijewantha HS, de Silva AP, Niriella MA, et al. Usefulness of Routine Terminal Ileoscopy and Biopsy during Colonoscopy in a Tropical Setting: A Retrospective Record-Based Study. Gastroenterol Res Pract 2014;2014:343849 